\title{
PETUAH BIJAK ORANG MAKASSAR: NILAI-NILAI KEAGAMAAN PADA KELONG MAKASSAR
}

\author{
The Sage Advice of Makassareese: \\ Religious Values at Makassareese Kelong \\ Muhammad As ' 'ad* \\ * Balai Litbang Agama Makassar \\ J1. A. P. Pettarani No. 72 Makassar \\ Email: muh as'ad(a),yahoo.com
}

Koreksi naskah I tanggal 5 September 2012. Koreksi naskah II tanggal 14 September 2012. Finalisasi Naskah 9 Oktober 2012

\begin{abstract}
Abstrak
Kelong Makassar adalah salah satu genre Sastera Makassar yang cukup tua dan terwariskan secara turun temurun dari generasi ke generasi. Semulapewarisannya secara lisan, kemudian tulisan di samping lisan, dan terakhir lebih banyak secara tulisa, Kelong sebagai sarana informasi berbagai aspek mengandung berbagai hal, termasukpetuah-petuah bijak. Setelah Islam diterima secara integrative dan budya masyarakat, nilai-nilai Islam menjadi bahagian dari kandungan kelong. Nilai-nilai Islam yang banyak diketemukan dalam kelong Makassar adalah akidah, iabadah (salat), dan akhlak.
\end{abstract}

Kata Kunci: Kelong Makassar, Aqidah, Ibadah, dan Akhlak.

\begin{abstract}
Kelong is one of genre of Makassareese Literary quite old and passed on from generation to generation from generation to generation. Originally inheritance is orally, then the writing on the oral side, and last more in writing. As a means Kelong contains information on various aspects of a variety of things, including advices sage. After Islam accepted integrative and social culture, Islamic values being part of the content of kelong. Islamic values are widely found in Makassareese kelong is a creed, worship (shalat), and morals.
\end{abstract}

Keywords: Makassareese kelong, creed, worship, and morals.

\section{PENDAHULUAN}

I ndonesia yang terkenal dengan semboyan Bhineka Tunggal Ika adalah negara kesatuan yang penduduknya sangat variatif, baik dari segi suku bangsa, budaya maupun pemelukan agama. Suku-suku bangsa di Indonesia banyak yang mencatat sejarah keemasannya pada masa lalu yang ditandai dengan berbagai tinggalan-tinggalan budayanya. Salah satu di antaranya adalah hasil sastera sebagai cerminan jati dirinya. Hasil sastera itu ada yang tersimpan dalam bentuk naskah (nakah kuno), ada pula yang tersimpan dalam lisan masyarakat pewaris penuturnya.

Tradisi lisan masyarakat mengandung nilai-nilai luhur yang mendasari keharmonisan hidup masyarakat dan tatanan kehidupannya sehingga merupakan kearifan lokal yang terwariskan. Nilai-nilai kearifan lokal itu bersifat universal sehingga keberlakuannya tidak terikat waktu dan tempat. Hanya saja pewarisnya banyak yang sudah melalaikannya sehingga terkesan terlupakan dan tidak teraplikasikan dalam konteks kekinian pada kehidupan masyarakat. Hal ini dikarenakan berbagai faktor, seperti dinamika perkembangan masyarakat yang sangat pesat karena pengaruh dari luar dirinya dan berdampak pada kondisi kehidupan yang jauh dari harapan, seperti ketidah harmonisan masyarakat.

Nilai-nilai luhur yang tersimpan dalam kearifan lokal berupa petuah pijak, bila teraplikasikan dalam kehidupan masyarakat dapat menciptakan tatanan kehidupan yang bermartabat sehingga tercipta masyarakat madany. Setiap warganya merasakan ketenteraman karena terlindungi hak asasinya dan merasa memiliki tanggung jawab bersama anggota masyarakat lainnya dalam kehidupan bermasyarakat. Mereka menyadari tuntutan pada dirinya untuk memelihara rasa keadilan masyarakat dalam arti adanya keseimbangan antara hak dan keawajiban. 
Nilai-nilai luhur dalam petuah bijak itu sejalan dengan nilai-nilai agama yang dianut oleh masyarakat. Dalam proses perkembangan dan transformasi nilai, kearifan lokal berupa petuah bijak diwarnai oleh nilainilai agama yang dianut masyarakatnya. Masyarakat Indonesia, termasuk yang berada di Sulawesi Selatan merupakan umat beragama yang peduli terhadap ajaran agamanya sejak dari dahulu. Reposisi nilai-nilai luhur yang tersimpan dalam berbagai tinggalan budaya diperlukan dalam merajuk kehidupan yang bermartabat dewasa ini, yaitu perwujudan kehidupan sosial yang harmonis, rukun, dan damai di kalangan umat beragama.

Menyadari hal itu, Balai Litbang Agama Makassar mencurahkan perhatiannya terhadap warisan budaya yang bernilai tinggi ini. Inventarisasi dan kajian terhadap berbagai warisan budaya di Kawasan Timur Indonesia telah dilakukan dalam rangka upaya reaktualisasi dan reposisi nilai. Warisan-warisan budaya yang telah dijadikan objek penelitian adalah naskah-naskah klasik keagamaan, masjid-masjid kuno, dan tradisi lisan masyarakat. Kajian-kajian terhadap warisan-warisan budaya tersebut terus dilakukan sebagai bagian dari pelestariannya dan seterusnya untuk pengaplikasiannya dalam masyarakat. Karena itu, perhatian Balai Litbanga Agama Makassar terhadap warisan budaya tersebut tetap berlanjut berupa penelitian-penelitian.

Salah satu penelitian yang dilakukan adalah yang hasilnya dituangkan dalam tulisan ini. Penelitan ini bertitik tolak dari pertanyaan penelitan yang diangkat sebagai permasalahan penelitian, yaitu:

1. Apa dan bagaimana Petuah bijak keagamaan berupa Kelong Makassar?

2. Bagaimana nilai-nilai keagamaan dalam petuah bijak berupa Kelong Makassar yang ada pada masyarakat?

Penelitian yang sangat relevan dengan penelitian ini ialah yang dilakukan oleh Nasruddin berjudul, Nilai Relegi dalam Kelong Makassar. Penelitian ini mengungkap nilai religi Islam dalam kelong Makassaryang mencakup beberapa aspek, yaitu: aqidah berupa kebesaran dan kekuasaan Tuhan, kerasulan Muhammad, kebenaran kitab-Nya, pentingnya salat, kewaspadaan dalam ucapan dan perbuatan, serta pembersihan diri dari dosa. Kelong yang dikemukakan dalam penelitian ini sangat terbatas sebagai pembuktian, yaitu hanya 11 bait dan analis keagamaan yang dipegunakan adalah nalar keislaman.
Kajian lain yang dilakukan oleh Nasruddin yang sangat relevan ialah yang berjudul Nilai Moral dalam Pappasang Makassar. Di antara hal yang dikemukakan penulisnya adalah pappasang yang dikemas dalam kelong Makassar, termasuk yang berisi keagamaan (Islam). Hanya saja, kelong yang dikemukakan juga sangat terbatas dan analisis wacana Islam.

Penelitian ini berusaha mengemukakan kelong Makassar yang berisi nilai-nilai agama Islam lebih banyak lagi termasuk yang telah dikemukakan dalam kedua kajian tersebut dan menganalisisnya sesuai dengan rujukan Islam atau pendekatan teologis.

Penelitian ini merupakan penelitian deskreptif kualitatif yang berusaha mengemukan kelong Makassar yang mengandung petuah bijak keagamaan yang diketemukan dalam masyarakat di Propinsi Sulawesi Selatan dan mendeskrepsikan makna dan nilai-nilai agama Islam yang terkadung di dalamnya. Semula sumber informasi fe/ongMakassar dari tokoh masyarakat dan dari tulisan, namun kenyataannya semua yang diketemukan bersumber dari tulisan. Tulisan yang dijadikan rujukan utama ialah: 1. Kelong dalam Sastera Makassar.2. Sangkarupa Kelong Mangkasarak, 3. Pantun-Pantun Makassar. 4. Nilai Edukatif Pappasang Makassa. Pendekatan yang dipergunakan dalam pengkajian kelong sebagai karya sastera adalah pendekatan fragmatik yang memandang bahwa karya sastera diciptakan pengarang hanyalah berupa alat atau sarana untuk menyampaikan pendidikan (dalam arti Luas) kepada pembaca. Yang menjadi objek analisis sastera bukanlah karya sastera itu sendiri (objek estetis), melainkan nilai-nilai (objek ekstra estetis) yang bersifat praktis (fragmatik) yang tercermin dalam karya sastera.

\section{TEMUAN DAN PEMBAHASAN}

\section{Gambaran I mum KelongMakassar}

Sebelum berbicara tentang kelong Makassar, terlebih dahulu dikemukakan sekilas tentang orang Makassar dan Bahasa Makassar. Dewasa ini wilayah masyarakat Makassar meliputi Kabupaten Gowa, Takalar, Jeneponto, Bantaeng, Maros, Pangkajene Kepualuan, Selayar dan Kota Makassar. ${ }^{2}$ Kabupaten Pangkajene Kepulauan dan Kabupaten Maros sebagai daerah perbatasan, juga merupakan daerah orang Bugis; demikian pula Kabupaten Bulukumba, selain dihuni oleh orang Bugis juga beberapa wilayahnya merupakan daerah orang Makassar. Suku Makassar

Nasruddin. Nilai Religi dalam Kelong Makassar. Dalam Sawerigading. 12 Oktober 2000. h.35.

Jemmain. Refleksi Sosial Masyarakatdalam Sastera Lisan. Dalam Bunga Rampai Hasil Penelitian Bahasa dan Sastera. No. 15. Anil 2008. h. 51. 
dalam kehidupan sehari-hari pada umumnya masih terikat oleh sistim norma dan aturan-aturan adatnya yang dianggap luhur dan keramat. Keseluruhan sistim norma dan aturan-aturan adat itu disebut panngadakan(Bugh; $\quad$ panngadereng). ${ }^{3}$

Mattulada mengemukakan: Acapkali orang memahami panngadereng (panngadakang) sama dengan aturan-aturan adat dan sistim norma saja. Panngadereng (panngadakang) meliputi selain aspek-aspek norma dan aturan-aturan adat, yaitu halhal yang ideal, yang mengandung nilai-nilai, normanorma, juga meliputi hal-hal yang mengandung prilaku seseorang dalam kegiatan sosial.4Selanjutnya secara rinci dikemukakan unsur-unsur panngadereng (panngadakang) yang meliputi: 1. Ade' meliputi segala keharusan bertingkah-laku dalam semua kehidupan bermasyarakat; 2. Bicara, yang bertalian dengan segala kegiatan dan konsep-konsep tentang masalahperadilan; 3. Rapang, yangmenjaga kepastian dan kesinambungan dari keputusan hokum tak tertulis dari masa yang lampau sampai sekarang, dengan kasus yang sedang berlangsung; 4. WarV yang menata klasifikasi segala benda, peristiwa dan segenap aktivitas dalam kehidupan masyarakat; 5. Sara', yang ditetapkan setelah Islam diterima sebagai agama resmi dalam kerajaan (berkaitan dengan syariat Islam).

Penggunaan bahasa merupakan pembeda yang menonjol antara suku Makassar dan suku Bugis, salah satu suku lainnya di Sulawesi Selatan, sehingga pada wilayah-wilayah tertentu yang penduduknya mahir pada dua bahasa tersebut ditandai dengan pemakaian secara mayoritas sehari-hari. Dalam lingkup kelompok bahasa Makassar sekarang ini biasanya ditonjolkan lima macam dialek, yaitu: dialek Lakiung, dialek Turatea, dialek Bantaeng, dialek Konjo, dan dialek Bira-Selayar. ${ }^{6}$ Dialek Lakiung pada umumnya dipergunakan di Kota Makassar, Kabupaten Gowa dan Kabupaten Takalar, dialek Turatea dipergunakan di Kabupaten Jeneponto, dialek Bantaeng dipakai di Kabupten Bantaeng, Dialek Konjo dipergunakan di Kabupaten Bulukumba, dan dialek Bira-Selayar dipergunakan di Ujung Bira Kabupaten Bulukumba dan Kabupaten Selayar.

Bahasa merupakan warisan budaya yang diturunkan secara turun temurun, dari generasi ke generasi sejak dahulu kala di kalangan etnis pendukungnya. Bagi masayarakat Bugis Makassar, pewarisan bahasa secara turun-temurun pada mulanya melalui bahas lisan; dan setelah mengenal tulisan pewarisan bahasa melalui tulisan di samping lisan. Pewarisan bahasa melalui tulisan berkaitan erat dengan simbol bahasa tulis yang dikenal dengan aksara. Tidak banyak suku-suku bangasa yang jumlahnya cukup banyak di Nusantara Indonesia yang memiliki aksara tersendiri.

Orang Bugis dan Makassar memiliki aksara tersediri yang dikenal dengan aksara lontarak. Aksara lontarak merupakan warisan dan kekayaan budaya yang sangat berharga, yang merupakan simbol dan identitas diri diwariskan bersama dengan pewarisan bahasa Bugis dan Makassar terutama kesusasteraannya. Aksara lontarak bagi orang Makassar berbeda jumlah hurufhya dengan aksara lontarak bagi orang Bugis karena ada 4 huruf dalam bahasa Bugis tidak dipakai dalam bahasa Makassar. Aksara lontarak bagi orang Makassar berjumlah 19 huruf, sedang bagi orang Bugis berjumlah 23 huruf. Huruf-huruf ngkak, mpak nrak, dan ncak adalah tambahan huruf bagi orang Bugis yang tidak dipergunakan orang Makassar. Untukjelasnya huruf-huruf tersebut tersusun sebagai berikut:

ka ga nga (ngkak); pa ba ma (mpak);

ta da na (nrak); cajanya (ncak);

ya ra la wa sa a ha.

Kesusasteraan Makassar ( ${ }^{\text {" }}{ }^{a}$ Bugis) pada mulanya diwariskan secara lisan (tradisi atau sastera lisan). Selanjutnya banyak sastera lisan ditulis dan disebut sastera tulis dan diwariskan melalui tulisan. Pewarisan karya sastrea yang bernilai tinggi secara lisan dan tulisan berjalan beriringan dan terkadang secara bergantian. Bahkan akhir-akhir ini sastera tulis lebih menonjol, tidak banjyak lagi kalau tidak dikatakan tidak ada lagi orang-orang yang menghafal dan mampu menuturkan sastera lisan itu.

Kesusasteraan Makassar meliputi: 1. Prosa, 2. Prosa liris, dan 3. puisi. Prosa dalam kesusasteraan Makassar dapat dibagi atas: a. rupama (dongeng), b. pau-pau, dan c. po//«r/o/oa «g(riwayat/silsilah). Prosa liris dalam kesusasteraan Makassar ada beberapa macam, yaitu: a. sinrilik, b. bust timurung c. pakeso-keso, d. royong, e. ceu, f. kurru-kurru jangang, g. turianang. Puisi dalam kesusasteraan Makassar terdiri atas: a. doangan, b. paktio bunting, c. aru, dan d. kelong.

*Ibid. h. 52

Mattulada. Sejarah, Masyarakat, dan Kebudayaan Sulawesi Selatan. Makassar: Hasanuddin University Press. 1998.

'Ibid. h. 87-89.

Palengkahu dkk redaksi. Peta Bahasa Sulawesi Selatan. 1974. h. 10. 
Kelong dibedakan: kelongmak-mdk, kelongtau lolo, dan kelong tau toa. Kelong tau toa berisi nasehat atau pendidikan dan disebut kelong panngajaran.'

Dalam khazanah kesusasteraan Makassar terdapat jenis kesusasteraan klasik yang mengandung ajaran moral. Masyarakat pendukungnya menamakannyapappasang. 'Pappasang ada yang berbentuk kelong dan adapula yang berbentuk paruntuk kana. Yang paling banyak ialah pappasang yang disampaikan dalam bahasa bebas."

Kelong dalam kesusasteraan Makassar digolongkan dalam suatu genre puisi Makassar. Bentuknya hampir sama dengan pantung dalam sastera Indonesia, yaitu masing-masing terdiri atas empat larik (baris) dalam satu bait. Akan tetapi kelong mempunyai karakteristik atau sifat-sifat tertentu, yakni: 1) kelong terikat dalam pola persukuan kata yaitu larik pertama 8 suku kata, larik kedua 8 suku kata, larik ketiga 5 suku kata, dan larik keempat 8 suku kata; 2) kelong dapat selesai atau mengandung suatu pengertian yang lengkap dengan satu bait saja, tetapiu dapat pula terdiri atas beberapa bait. Akhir-akhir ini kelongtdah mengalami perkembangan barudari segi persukuan katariya. Ada yang berpola 8888 suku kata, 9999 suku kata, bahkan ada yang 10 suku kata dalam satu larik. ${ }^{10}$ Dalam aksara lontarak, satu suku kata dilambangkan dengan satu huruf, sehingga bila kelong itu ditulis dengan huruf lontarak maka rumus kelong itu adalah 8858 huruf.

Kelong sebagai warisan budaya masyarakat Makassar yang diwariskan secara turun temurun merupakan bukti ketinggian budaya orang Makassar. Berbagai nilai-nilai luhur terkandung di dalamnya. Kelong mengandung falsafahhidup, ajaran moral, ajaran karakter, sikap dan prilaku terpuji, serta ungkapan perasaan. Trasnformasi dan transmisi nilai-nilai tersebut melalui media bahasa sastera berupa kelong di samping media bahasa bentuk lainnya, prosa atau prosa link berlangsung sejak dahulu. Setelah agama Islam diterima secara integratif dalam tatanan kehidupan (panngadakkan), nilai-nilai dan ajaran agama menjadi bahagian penting dari isi kelongdm bentuk sastera lainnya

Kelong, dengan demikian memiliki fungsi penting dalam kehidupan masyarakat. Zainuddin Hakim mengemukakan 5 fungsi kelong, yaitu: 1. Sebagai media pendidikan, 2. Sebagai media hiburan, 3. Sebagai pembangkit semangat juang, 4. Sebagai media komunikasi, dan 5. Sebagai produk dan pelestarian budaya. Selanjutnya dikemukakan dua macam nilai pendidikan, yaitu kelong yang berbicara tentang hubungan manusia dengan Tuhan digolongkan sebagai kelong bersifat keagamaan; sedang kelong yang berbicara tentang adat istiadat dan tata cara bergaul dengan sesama manusia termasuk pendidikan sosial."

Islam sebagai agama paripurna mengatur hubungan manusia dengan Tuhannya (Allah swt. yang disebut hablun min Allah dan hubungan manusia dengan sesamanya, termasuk lingkungannya, yang disebut hablun min annas. Berkaitan dengan itu nilai agama yang terungkap dalam kelong Makassar bukan hanya hubungan manusia dengan Tuhannya, tetapi juga hubungan manusia dengan manusia. Dengan demikian, aspek-aspek agama yang terekam dalam kelong dapat dikategorikan: 1. Aqidah atau keimanan, 2. Ibadah (rukun Islam), 3. Muamalah, dan 4. Akhlak. Meskipunaspek akhlak dapat tumpang tindih dengan aspek lainnya, tetapi tetap dipisahkan dengan penekanan pada aspek moral, kecuali berkaitan dengan aspek muamalah.

Agama Islam adalah agama dakwah. Setiap umat Islam memikul tanggung jawab sebagai da'i sesuai dengan kemampuan dan kapasitas yang dimilikinya. Dengan demikian kelong selain berfungsi sebagai media pendidikan Islam, juga berfungsi sebagai media dakwah Islam.

\section{Nilai-Nilai Agama dalam Kelong Makassar.}

Sebelum mengemukakan nilai-nilai agama dalam Kelong Makassar, terlebih dahulu dikemukakan sejumlah kelongyang mengandung nilai-nilai agama Islam, dalam hal ini berkaitan dengan aqidah, ibadah dan akhlak yang sempat dinventarisir dalam penelitian ini. Kelong yang dikemukakan tidak dikelompokkan secara terpisah karena dalam satu bait kelong ada yang mengandung lebih dari satu aspek Islam tersebut. Namun demikian urutan bait-bait kelong tetap memperhatikan aspek-aspek Islam yang tiga tersebut.

Jemmain. Refleksi Sosial Masyarakat Makassar dalam Sastera Lisan. dalam Bunga Rampai Hasil Penelitian Bahasa dan sastera. No. 15. April 2008. h. 60-61.

\footnotetext{
Nasaruddin. Ajaran Moral dalam Pappasang Makassar, dalam Bunga Rampai Hasil Penelitian Bahasa dan sastera. 1997. h. $264-265$.

' Hakim. Nilai Edukatif Pappasang Makassar, dalam Bunga Rampai Hasil Penelitian Bahasa dan Sastera. 1999. h. 297.

${ }^{10}$ Nasaruddin. Nilai Religi dalam Kelong Makassar. Dalam Sawerigading. Nomor 12 Oktober 2000. h. 36-37.

Zainuddin Hakim. Kelong dan Fungsinya dalam Masyarakat. Dalam Bunga Rampai Hasil Penelitian Bahasa dan Sastera. 1998. h. 7-8
} 


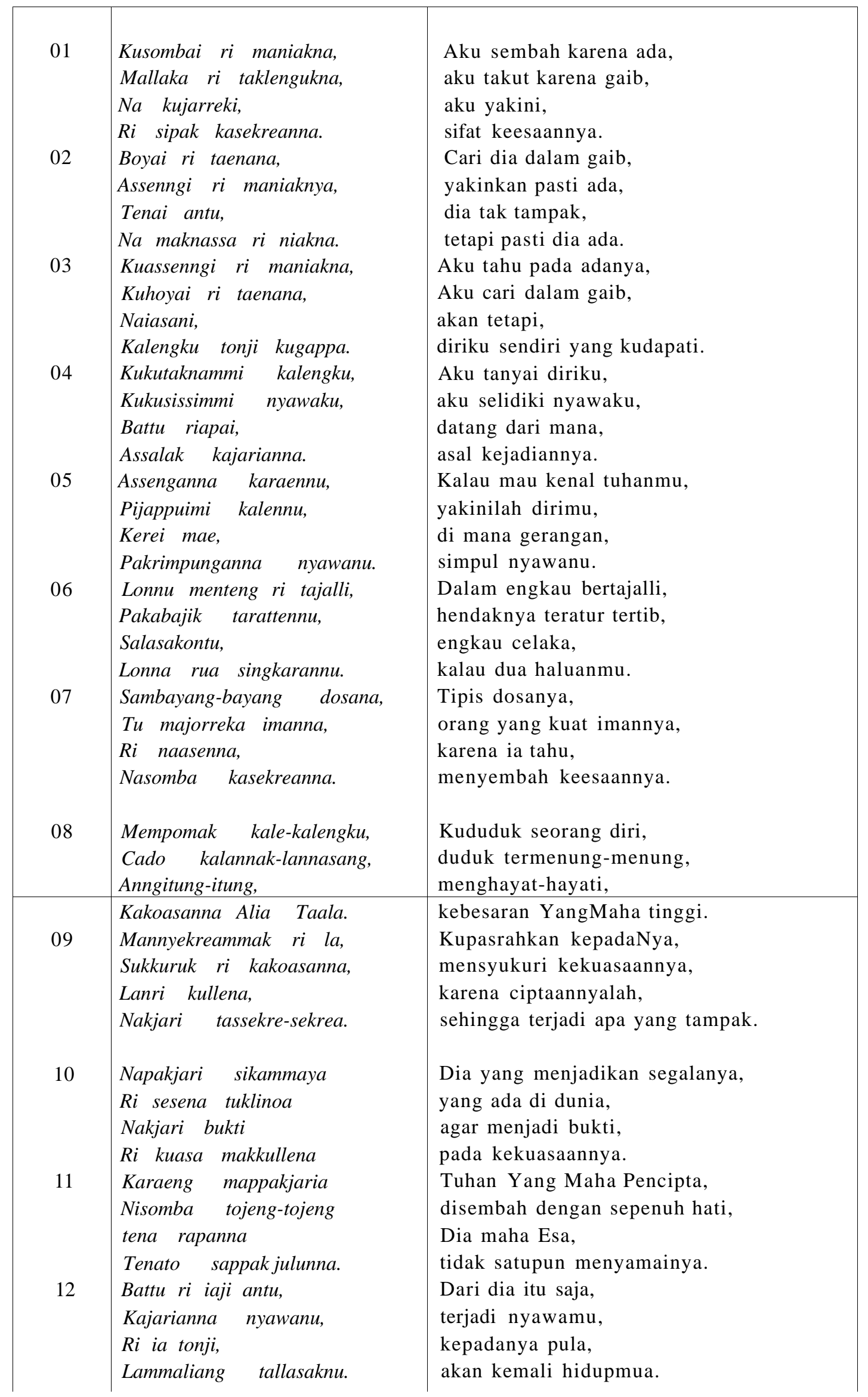


Punna erokko masunngu, Tantanngi appakruaya,

Iamintu,

Dosa kaminang lompo. Tappako sibajiknaya Kittakna Allataala

Tena nappau

Nakbicara balle-balle.

Punna niak tu tatappa

Kittakna Alia Taala

Bilisik antu

Ammenteng kale-kalenna.

Inakkepa manngurangi

Lonnu lingkamo ri anja

Mappak rikongang

Lonnu sallang ri suruga.

Surugaji borik tojeng,

Lino kiinrangji anne,

Kiparek tonji,

Loklong pakmari-marinna.

Kasi-kasi kalumannyang,

Labbirik iaka tuna,

Sikontu ummak,

Sekreji la namangei. •

Jnai-nai sallanga,

Majai gauk kodinna,

Gappami antu,

Passessaya ri naraka.

Pannassai sahadaknu.

Sekreji Alia taala,

Nakbi Muhammad,

Suro tumatappakna.

Assengngi ri sahadannu

Sekre tumappakjarinnu

Nabbi Muhammad

Suro malakbirikna.

Punna tanupatok sahadaknu,

Tanusikko sambayannu,

Ebarak lepa-lepa,

Tena guling samparqjan.

Sahadaknu kana tojeng,

Sambayangnu gauk tojeng,

Nanuntangi,

Atinnu ri kontu tojeng.

Sahadak bale-balena,

Sikkirik tubaranina,

Napassikkokna,

Sambayang lima waktu.
Jika engkau ingin mulia, hindarkanlah musyrik,

itulah dia,

dosa yang paling besar.

Percaya sesungguhnya,

kitab Allah Taala,

tidak menyampaikan,

ucapan dusta.

Jika ada orang tak beriman,

terhadap kitab Allah,

dialah Iblis,

berdiri sendiri.

Nanti kau yang mengingat,

jika engkau jadi maut,

mondoakan,

kelak engkau di dalam Surga.

Hanya Syurga perkampungan kekal,

dunia ini hanyalah pinjaman,

hanya dijadikan,

bernaung dan beristirahat.

Kaya miskin,

mulia hina,

semua umat,

hanya satu yang akan dituju.

Siapa saja orang Islam,

banyak perbuatan jeleknya,

mendapatlah ia,

siksa dalam neraka

Nyatakanlah sahadatmu,

Alia itu Esa,

Nabi Muhammad,

Rasul terpercaya.

Ketahuilah dalam sahadatmu, satu yang menciptakanmu,

Nabi Muhammad,

Rasul-Nya yang terpercaya.

Jika engkau tidak menyimpul sahadaknu, tidak mengikat salatmu,

bagai perahu.

yang tidak mempunyai kemudi dan jangkar.

Sahadatmu adalah tutur kata yang benar, salatmu adalah perbuatan yang benar, kamu tetapkan,

hatimu pada kebenaran.

Sahadak andalanna,

zikir orang baraninya,

pengikatnya,

salat lima waktu. 


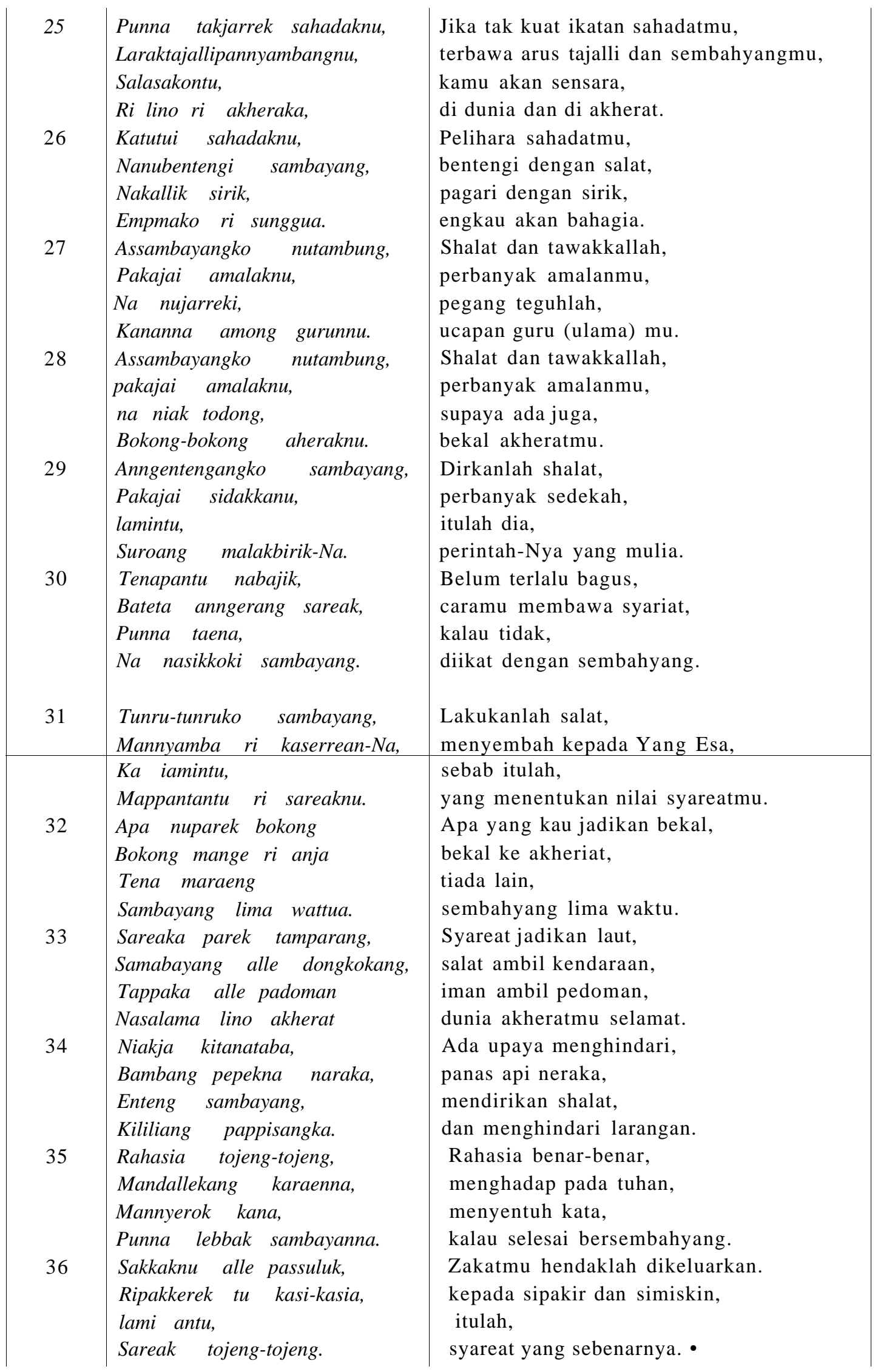


Pittara jekne inunna,

Karoban nalamba-lamba,

Naikka haji,

Naparek pabbisa bawa.

Pittaranu alle pabbissa,

Tobatnu alle pencuci.

Nasambayangnu,

Tajalli tojeng-tojeng.

Barang-barannu tangkasi,

Batang kalennu cikonongi,

Natekaknu,

Makkaraeng ri niakna.

Kakdek nakke jangan-jangan,

Kuribbakiji butta makka,

Nakusukjuki,

Bangkenna baitullaya.

1 Giok bajik nigaukang

Parallu nipakajai

$R i$ nиаsеnпиа

Karaeng siagang nabbinnu.

Gauk bajik nigaukang,

Parallu nilaku-laku

Iami antu,

Sambayang lima wattua.

Tette-tetterekko tobak,

$R i$ gettengang tallasaknu,

Mateko sallang

Nanusassalak kalennu.

Angnganro-anroko tobak,

$R i$ gintingan tamatenu,

Mateko sallang,

$\mathrm{Na}$ nusassalak kalennu.

Tutu laloko ri kana,

Ingakko ri panggaukang,

Kodi gauknu,

Kodi todong balasakna.

Tutulaloki ri kana,

ingakki ri panngaukang,

baji giotta,

Baj itodong balasanna.

Resopa siagang tambung,

Ri karaeng malompoa,

Nanampa niak,

Sunggu lanikammai.

Empo sunggu panna-panna,

Tenne jannaya kayao,

Naya lanrinna,

Reso satunggu-tunggu.

Tunaya na kasi-asi,

Labbirik na kalumannyang,

Allah Taala,

Erok nampa kajariang.
Zakat fitrah air minumnya,

kurban sarapannya,

naik haji,

pencuci mulutnya.

Zakat fitrahmu pembersih,

tobatmu pencuci,

sedang salatmu,

tajalli yang sebenarnya.

Bersihkan hartamu,

jernihkan tubuhmu,

itikadmu,

meyakini keberadaannya.

Sekiranya aku jadi burung,

saya akan terbeng ke Mekah,

$\mathrm{ku}$ besujud,

di kaki Baitullah.

Pekerjaan baik dilakukan, pardhu diperbanyak, setelah mengetahui, Tuhan dan nabimu.

Amal baik dilakukan, wajib diperbanyak, itulah dia,

semabahyang lima waktu.

Cepat-cepatlah bertobat,

selama engkau masih hidup,

kelak kau meninggal,

engkau menyesali dirimu.

Lekas-lekaslah tobat,

sebelum engkau mati,

nanti engkau tiba-tiba mati,

engkau sesali dirimu.

Hati-hatilah dalam berkata,

ingatlah dalam perbuatanmu,

buruk perbuatanmu,

buruk pula imbalannya.

Hati-hatilah dalam berkata,

Ingatlah dalam perbutan,

Baik perbuatanmu.

Baik pula balasannya.

Bekerja disertai tawakkal, kepada Tuhan Yang Agung, baru ada,

bahagia digapai.

Bahagia cita-citakan,

kemakmuran idam-idamkan,

melalui,

bekerja dengan tekun.

Hina dan miskin, terhormat dan kaya,

Allah Taala,

berkemauan baru bias terjadi. 


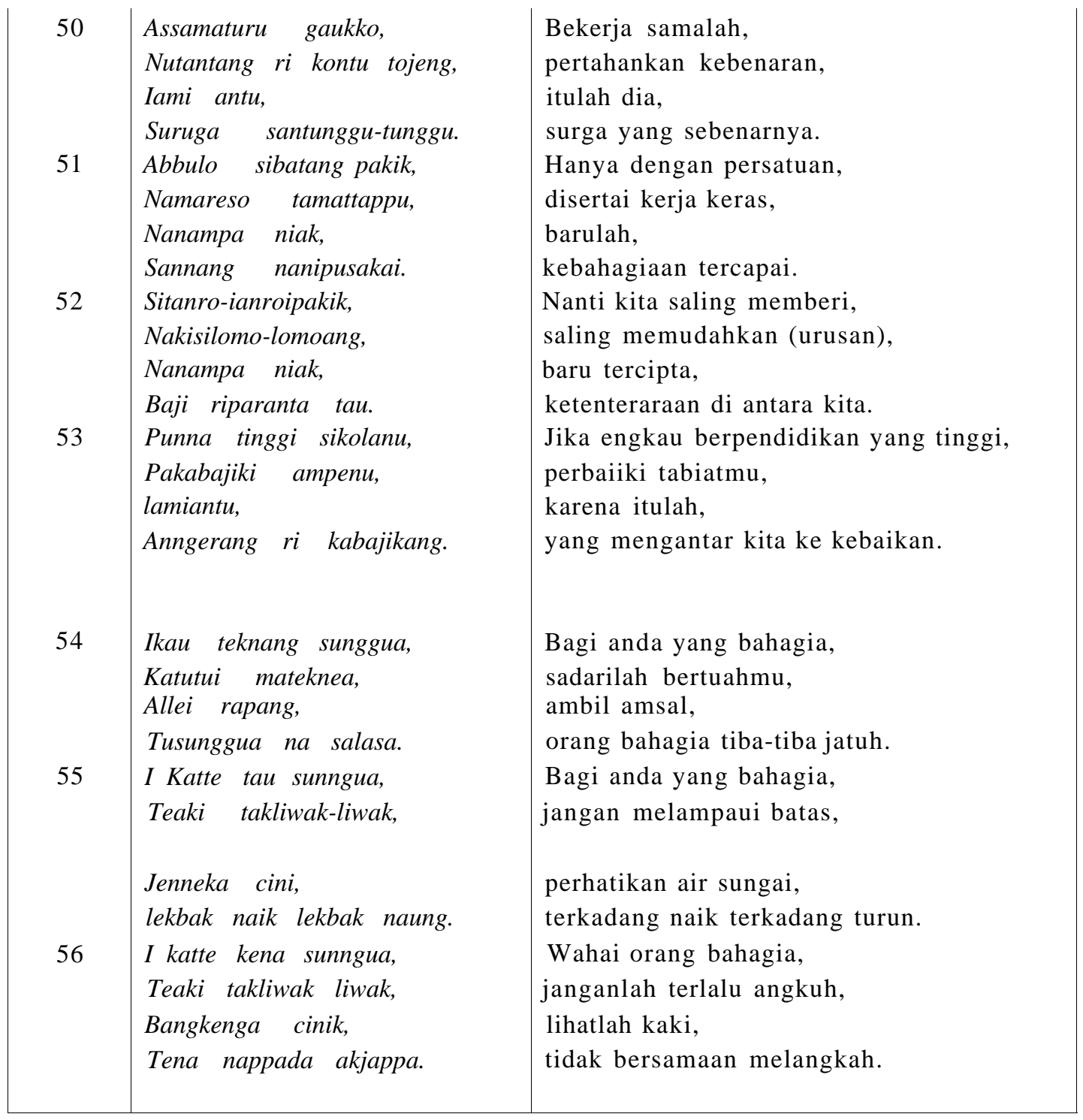

Nilai-nilai agama Islam dalam kelong Makassar yang dikemukakan dalam tulisan ini dikelompokkan pada aspek-aspek Islam, yaitu: Aqidah, ibadah, dan akhlak.Aspek aqidah, ibadah, dan akhlak berdasarkan penjelasan Jibril kepada Nabi Muhammad saw. dalam satu riwayah, Iman ialah engkau percaya kepada Allah, Malaikat-Nya, kitab-kitab-Nya, rasul-rasulNya, dan hari akherat, serta engkau percaya tentang qadar-Nya, baik atau buruk. Islam ialah engkau bersaksi bahwa sesungguhnya tiada Tuhan selain Allah dan sesungguhnya Muhammad adalah rasul-Nya, engkau mendidikan salat, engkau mengeluarkan zakat, engkau puasakan Ramadan, engkau berhaji di Baitullah bagi yang mampumelaksanakannya. Ihsan ialah engkau menyembah kepada Allah seakan-akan engkau melihatnya, dan jika engkau tidak melihat-Nya sesungguhnya Dia melihatmu (al hadits).
Hadits tersebut menjelaskan tentang rukun Iman yang enam dan rukun Islam yang lima. Rukun Iman pertama, yaitu percaya kepada Allah mencakup banyak aspek berkaitan dengan-Nya, sebagai satu-satunya pencipta, pemilik, penguasa, dan pemelihara yang sesungguhnya. Dengan demikian, Allah Maha Esa (qs. Al-Ikhlas: 1), hanya kepada-Nya yang kita menyembah dan hanya kepada-Nya kita minta pertolongan (qs.alFatihah:5). Kita yakini adanya Allah (maniak-Na) tetapi karena ia Maha gaib, kita tidak dapat melihatNya (tallenguk- $\mathrm{Na}$ atau taena-Na). Meskipun ia tidak terlihat kita, takut kepada-Nya dan keyakinan kita atas ada-Nya dan keesan-Nya harus diperkuat, tidak boleh ada keraguan. Hal ini terlihat dalam Kelong 01-03.

Adanya Allah dapat dibuktikan dengan keberadaan diri kita sebagai kenyataan. Keyakinan kita atas adanya Allah dan kekuasaan-Nya diperkuat dengan 
nalar kita pada diri kita, yang terdiri dari unsur jasmani dan rohani, dari mana asal kejadiannya. Hal ini terungkap pada kelong 04 dan 05. Bukti-bukti kekuasaan Allah yang kita harus renungkan, terlihat pada semua makhluk yang diciptakan-Nya. Hal ini terlihat pada kelong 08-10. Kita semua berasal dari Allah dan kepada-Nya kita semua akan kembali. Keyakinan demikian ini terungkap pada kelong 12. Kalau kita sudah memahami diri kita demikian maka bagaimana mengaplikasikan hal itu dalam wujud iabadah (kelong 13).

Pengabdian kita sesungguhnya hanya kepada Allah, tiada yang serupa dengannya dan tiada duanya (kelong 11). Keyakinan ini harus dipegang erat-erat, karena jika tidak kita akan rusak sendiri (salasakontu lonna rua singkaruannu (kelong 06). Karena itu jika kita ingin selamat mendapat kemuliaan hindarkan diri kita dari kemusyrikan yang merupakan dosa besar yang tidak terampuni ((kelong 14). a(kelong 14) llah berfirman:Sesungguhnya Allah tidak mengampuni dosa kemusyrikan (qs. An-Nisa:48).

Al Qur'an yang diturunkan Allah swt. bagi umat Islam diyakini sebagai kitab yang isi dan kandung semua kebenaran, tanpa keraguan, apa lagi kebohongan. Allah berfirman: Kitab itu (Al Qur 'an) tidak ada keraguan di dalamnya sebagai petunjuk bagi orang bertaqwa (qs. Al Baqarah: 2). Hal ini harus dipercayai penuh keyakinan (kelong 15). Orang yang tidak mempercayai kebenaran al Qur'an dianggap sebagai Iblis yan g terisolasi (kelong 16).

Nabi Muhammad merupakan rasul pilihan Allah yang dikenal dengan asyraful anbiyai wal mursalin (yang termulia di antara nabi dan rasul) dan terkenal kejujurannya sehingga di gelar al-Amin. Dalam kelong Makassar dikemukakan, Nakbi Muhammad suro tumatappak-Na (20) dan Nakbi Muhammad suro malakbirin-Na (21).

Islam mengajarkan bahwa setelah kehidupan dunia masih ada kehidupan akherat. Semua manusia, kaya miskin, mulia hina, akan kembali hanya kepada Allah untuk mempertanggung jawabkan kehidupannya di dunia (kelong $\backslash$ ). Kehidupan dunia hanya bagaikan tempat persinggahan yang bersifat sementara, sedang Syurga yang disiapkan bagi orang yang beruntung merupakan tempat yang sebenarnya (surugaji boring tojeng (18) yang diharapkan dan didoakan, baik untuk diri sendiri maupun orang lain (kelong 17). Di samping Syurga sebagai tempat kesenangan, Allah menciptakan neraka sebagai tempat kesengsaraan.
Orang Islam yang banyak perbuatan buruknya akan disiksa dalam neraka (kelong 20)Allah menjelaskan: Barang siapa yang berat timbangannya (lebih banyak kebaikannya) maka ia berada pada kehidupan yang diredai (Syurga), dan barang siapa yang ringan timbangannya (keburukannya lebih banyak), maka tempatnya adalah neraka Hawiyah (qs. Al Qari'ah:6-9).

Keyakinan atas keesaan Allah dan kerasulan Muhammad diikrarkan oleh seorang Muslim berupa ucapan yang dikenal dengan syahadatain. Hal ini dinyatakan dalam kelong 20 dan 21. Kesempurnaan syahadat (iman) bagi seorang Muslim, bukan terbatas ikrar dengan lidah dan pembenaran dalam hati, tetapi dinyatakan dalam perbuatan. Di anatar ulama mendefinisan iman dengan: ikraru bil lisan, wat tashdiqu bil qalbi, wal amalu bil arkan. Wujud aplikatif syahadat paling utama adalah salat. Hal ini diungkap pada kelong 23. Karena itu syahadat dan salat tidak dapat dipisahkan; syahadat bagian penting dari salat. Selama hidup seorang Muslim, syahadat selalu dijaga, tidak bisah lepas. Pengikat syahadat adalah salat (kelong 24). Salat sebagai benteng agar syahadat tidak goyang (kelong 26). Apabila seorang Muslim tidak kuat berpegang pada syahadatnya, dalam hal ini pelaksanaan salatnya kurang beres maka kesensaraan baginya (kelong 25).

Dalam ajaran Islam salat lima waktu sangat dipentingkan. Selain merupakan kewajiban (qs. An-Nisa: 103). atau perintah yang harus dilaksanakan (qs.alBaqarah:43) juga memiliki posisi penentukan bagia amalan-amalan lainnya. Amalan seorang hamba yang pertama-tama dihisab di Hari Akherat adalah salat; jika amal baiknya akan baik dan jika rusak amalan lainnya rusak.(al Hadits). Bahkan salat merupakan pembeda antara orang mukmin dengan orang kafir (al Hadits). Perintah salat termuat dalam kelong 27, 28, dan 29. Perintah salat dikemukakan bersama perintah memperbanyakamalan-amalan lain (kelongll dan28). Perintahmendirikan salat sangat ditekankan ulama untuk dipegangi erat-erat (kelong 27), dan merupakan bekal untuk kehidupan akherat kita (kelong 28 dan 29).

Pelaksanaan salat merupakan simbol sejauh mana kita berpegang pada syareat Islam. Hal ini terungkap dalam kelong 31, 32, dan 34. Dan merupakan upaya untuk menghindarkan diri dari siksa api neraka bersama upaya lainnya, yaitu menjauhi larangan Allah (kelong 33). Secara fungsional, sesungguhnya shalat mencegah perbuatan buruk dan kemungkaran (qs. Al-Ankabut:45). 
Perintah salat tidak terpisahkan dengan perintah menunaikan zakat. Allah berfirman: Dirikanlah salat dan tunaikan zakat. (qs. Al-Baqarah:43). Zakat adalah untuk fakir miskin, sehingga merupakan juga simbol pelaksanaan syareat yang benar \{kelong 36). Zakat merupakan ibadah yang menentukan kesempurnaan seorang hambajika dilakukan bersama dengan ibadah dan pegangan lainnya, seperti: ibadah Kurban, ibadah Haji, bertaubat, salat, dan keyakinan adanya Allah. Hal ini terlihat dalam kelong 37-39.

Pelaksanaan ibadah Haji dengan berkunjung ke Baitullah merupakan angan-anagan, keinginan dan harapan bagi semua umat Islam. Hanya saja tidak semua umat memiliki istitha 'ah (kemampuan) sehingga bagi mereka yang demikian merupakan angan-angan sebagai mana digambarkan pada kelong 40 .

Akhlakul karimah(akh\ak mulia) merupakan hal yang sangat dipentingkan dalam Islam, bahkan salah satu misi kerasulan adalah menyempurnakan akhlakul karimah. Rasulullah bersabda: Sesungguhnya soya diutus untuk menyempurnakan akhlak mulia (al hadits). Tidak terdapat batas yang jelas antara.akhlak dengan akidah dan ibadah, karena ada akhlak berkaitan dengan Tuhan dan Nabi-Nya dan ada berkaitandengan sesama manusia, bahkan dengan alam lingkungan.

Sebagai konsekuensi atas pengakuan kita kepada Tuhan bersama Nabi-Nya, kita harus memelihara perbuatan yang baik dan memperbanyak melakukan ibadah yang fardu, terutama salat. Hal ini terungkap dalam kelong 41 dan 42. Sebagai manusia biasa, kita tidak luput dari kesalahan karena itu kita harus selalu bertaubat. Nabi bersabda, seтиa engkau berbuat salah, dan sebaik-baik orang yang bersalah yang segera bertobat (al Hadits). Kalu kita tidak bertaubat akan menjadi penyesalan nanti setelah meninggal. Hal ini dikemukakan dalam kelong 43 dan 44 .

Semua amal perbuatan manusia, baik berupa perkataan maupun perbuatan akan dibalaskan di akherat sebagai hari pembalasan; kebaikan dibalas dengan kebaikan (syurga) dan keburukan dibalas dengan keburukan (neraka). Allah berfirman, Barang siapa yang berbuat kebaikan meskipun sekecil zarrah (atom) akan dibalaskan, dan barang siapa yang berbuat kejahatan meskipun sekecil atom juga akan dibalaskan (qs. Al zalzalah: 7-8). Karena itu kita harus berhati-hati dalam perkataan dan waspada dalam perbuatan. Ucapan dan perbuatan baik kita harus pelihara, sebaliknya ucapan dan perbuatan jelek kita tinggalkan. Hal ini tergambar pada kelong 45 dan 46.
Dunia ini adalah tempat bekerja dan berusaha untuk kepentingan akherat. Nabi bersabda, ad-dunya mazra'atul akhiorah (al Hadits). Dengan demikian kebahagiaan dunia dan kebahagiaan di akherat dapat dirasakan dengan kerja yang sungguh-sungguh. Kerja dan usaha merupakan syarat untuk mendapatkan rekzi dari Allah, dengan demikian manusia sambil berusaha juga berserah diri kepada Allah. Hal ini tertuang dalam kelong $M$ dan 48. Allah lah yang mentukan kaya dan miskin seseorang, dengan firmannya, itulah fadlullah (rezki Allah), Dia brikan kepada siapa yang diingini-Nya (qs, al-Hadid: 21). Hal dikemukakan dalam kelongA9.

Sebagai makhluk sosial, manusia dalam bekerja dan berusaha tidak hanya mementingkan diri sendiri tetapi juga memperhatiakan kepentingan orang lain. Bekerjasama dan saling bantu merupakan hal yang dipentingkan Islam. Allah berfirman, bekerja sama dan saling membantulah dalam kebaikan dan ketaqwaan dan jangan bekerjasama dan saling membantu dalam perbuatan dosa dan permusuhan (qs.al-Maidah:2). Kebahagiaan hidup dan ketenterman dapat dirasakan dengan memelihara kerjasama dan saling membantu. Hal ini dikemukakan dalam kelong 50-52.

Hubungan baik dengan sesama manusia terpelihara dengan menghindari perangai-perangai yang tidak baik seperti kesombongan. Bahkan kesombongan akan mencegah seseorang masuk syurga. Rasul bersabda, tidak akan masuk syurga orang yang dalam hatinya terdapat kesombongan sekecil apapun (al Hadits). Ketinggian ilmu yang dimiliki jangan membuat kita sombong dan sebaliknya kita tetap memelihara budi pekerti yang baik. Hal ini dikemukakan dalam kelong 53. Kita harus menyadari bahwa manusia di dunia ini pada dasarnya "lebih kurang". Kehidupan ini pada dasarnya bagai pedati, terkadang di atas dan terkadang di bawah. Keadaan ini digambarkan dalam kelong5A-56.

\section{PENUTUP}

Sebagai penutup dalam tulisan ini dikemukakan empat kesimpulan yang penting untuk diketahui dan diaplikasikan, yaitu:

1. Kelong dalam masyarakat Makassar merupakan warisan dari leluhur yang masih terpelihara sampai saat ini. Kelong merupakan genre sastra Makassar yang memiliki karakteristik tersendiri. Hanya saja £e/cmgMakassar yang dahulu merupakan sastera lisan masyarakat, yang 
diketemukan dalam penelitian ini pada umumnya telah tertulis, hampir tidak diketemukan lagi beredar secara lisan dalam masyarakat.

2. Pelestarian£<?/o«g Makassar melalui tulisan kurang aplikatif dan fungsional, sehingga perlu perhatian para budayawan dan tokoh agama menyosialisasikannya dalam bentuk lisan dalam berbagai kesempatan. Salah satu bentuk pelestariannya secara lisan adalah diadakan festifal seni sastera yang berisi antara lain pembacaan kelong secara lisan

3. Nilai-nilai agama Islam menjadi bahagian dari kelong Makassar setelah Islam diterima secara resmi dan terintegratif dalam panngafdakang. Nilai-Nilai Islam padakelong Makassar yang diketemukan dalam masyarakat meliputi akidah / keimanan, ibadah, dan akhlak.

4. Kelong keagamaan itu perlu difungsikan sebagai media pendidikan, terutama pendidikan karakter. Demikian pula perlu difungsikan sebagai media dakwah Islam untuk menanamkan berbagai aspek-aspek Islam bersama dengan dalil-dalil agama lainnya.

\section{Daftar Pustaka}

Hakim, Zainuddin. 1992. Pasang danpanmtuk Kana dalam Sastera Klasik Makassar. Jakarta: Pusat Pembinaan dan Pengembangan Bahasa Departemen Pendidikan dan Kebudayaan.

1998. Kelong dan Fungsinya dalam Masyarakat. Dalam Bunga Rampai Hasil Penelitian Bahasa dan Sastera. Makassar: Balai Bahasa (1-69).

1999. Nilai-Nilai Edukatif Pappasang Makassar, dalam Bunga Rampai Hasil Penelitian Bahasa dan Sastera. Makassar: Balai Bahasa.

Jemmain. 2008. Refleksi Sosial Masyarakat Makassar dalam Sastera Lisan. Dalam Bunga Rampai Hasil Penelitian Bahasa dan Sastera. Makassar: Balai Bahasa (45-107).

Mattulada. 1998. Sejarah, Masyarakat, dan Kebudayaan Sulawesi Selatan. Makassar: Hasanuddin University Press.

Nappu, Sahabuddin. 1986. Kelong dalam Sastera Makassar. Jakarta: Proyek Penelitian bahasa dan Sastra Indonesia dan Daerah.

1997. Sangkarupa Kelong Mangkasarak. Jakarta: Pusat Pembinaan dan Pengembangan Bahasa, Departemen Pendidikan dan Kebudayaan.

Nappu, Sahabuddin dan J.S.Sande. 1991. Pantun-Pantun Makassar. Jakarta: Departemen Pendidikan dan Kebudayaan.
Nasruddin. 1997. Ajaran Moral dalam Pappasang Makassar. Dalam Bunga Rampai Hasil Penelitian Bahasa dan Sastera. Makassar: Balai Bahasa (264-335).

2000. Nilai Relegi dalam Kelong Makassar. Dalam Sawerigading. NO. 12 Oktober.Makassar: balai Bahasa Ujung Pandang (3449).

Pelengkahu, R.A. dkk. 1974. Peta Bahasa Sulawesi Selatan (Buku Petun juk). Ujung Pandang: Lembaga Bahasa Nasional Cabang III. 